\title{
Correction to: Treatment of stage II medication-related osteonecrosis of the jaw with necrosectomy and autologous bone marrow mesenchymal stem cells
}

\author{
Pit Jacob Voss ${ }^{1} \cdot$ Akihiko Matsumoto $^{2}$ - Esteban Alvarado ${ }^{3} \cdot$ Rainer Schmelzeisen $^{1} \cdot$ Fabian Duttenhoefer $^{1}$. \\ Philipp Poxleitner ${ }^{1}$
}

Published online: 5 February 2019

(c) The Society of The Nippon Dental University 2019

\section{Correction to: Odontology (2017) 105:484-493 https://doi.org/10.1007/s10266-017-0295-4}

In the Original publication of the article, the co-author has been misspelled as Fabian Duttenhöfer in the article "Treatment of stage II medication-related osteonecrosis of the jaw with necrosectomy and autologous bone marrow mesenchymal stem cells" published in October 2017, Volume 105, Issue 4 of Odontology. The correct name is "Fabian Duttenhoefer".

Correct author names is provided in this correction.
Publisher's Note Springer Nature remains neutral with regard to jurisdictional claims in published maps and institutional affiliations.

The original article can be found online at https://doi.org/10.1007/ s10266-017-0295-4.

Akihiko Matsumoto matsuaki@dent.kyushu-u.ac.jp

1 Department of Oral and Maxillofacial Surgery, University Medical Center Freiburg, Hugstetter Str. 55, 79106 Freiburg im Breisgau, Germany

2 Section of Oral and Maxillofacial Surgery, Division of Maxillofacial Diagnostic and Surgical Sciences, Faculty of Dental Science, Kyushu University, 3-1-1 Maidashi, Higashi-ku, Fukuoka 812-8582, Japan

3 Section of Orthodontics and Maxillofacial Surgery, Latinamerican University of Science and Technology, 100 metros sur del Periódico La República, San José, Barrio Tournón, Costa Rica 